\title{
Quality assessment of five pharmaceutical products of different brands marketed in Nigeria
}

\author{
Richard Odunayo Akinyeye ${ }^{1 *}$, Adeleke Adebanji Adepoju ${ }^{1}$, Joshua Iseoluwa Orege ${ }^{1}$ and \\ Adekunle Theophilus Adegbuyi ${ }^{2}$
}

\footnotetext{
${ }^{1}$ Department of Industrial Chemistry, Faculty of Science, Ekiti State University, P. M. B. 5363, Ado-Ekiti, Ekiti State, Nigeria.

${ }^{2}$ Department of Pharmacology and Toxicology, Faculty of Pharmacy, Federal University Oye-Ekiti, Ekiti State, Nigeria.

${ }^{*}$ Corresponding author Email: richard.akinyeye@eksu.edu.ng; richardakinyeye@gmail.com

Copyright @ 2021 Akinyeye et al. This article remains permanently open access under the terms of the Creative Commons Attribution License 4.0, which permits unrestricted use, distribution, and reproduction in any medium, provided the original work is properly cited.
}

Received 28th August, 2019; Accepted 3rd August, 2021

\begin{abstract}
Many pharmaceutical products have been reported to be substandard and counterfeit. About $15 \%$ of all drugs circulating in some parts of Africa and Asia are believed to be counterfeit, with figures rising to as high as $50 \%$. This study was therefore carried out to assess the quality of five groups of drugs of different brands manufactured by pharmaceutical companies in Nigeria. Qualitative and quantitative analysis were carried out on the drugs using United States, British and Indian Pharmacopoeias. Qualitative analysis investigated includes: friability test, hardness test, disintegration test, dissolution test, $\mathrm{pH}$, and weight uniformity for tablets; specific gravity, flow rate, $\mathrm{pH}$ and weight per ml of syrups. The quantitative analysis includes percentage purity and drug assay determination for different constituents using titrimetric, spectrophotometric and high performance liquid chromatographic (HPLC) methods. From the study, it was established that the Nigeria brands of pharmaceutical products sampled generally conformed to the established qualitative and quantitative specifications. There was however a short slight fall in the chromatographic assay for vitamin $\mathrm{B}_{6}$ in the Blood tonic from one company and similarly, the vitamin $\mathrm{B}_{1}$ in the Blood tonic of one company were at variance to those from other companies. The result for the statistical analysis shows that there is uniformity in weight of all tablets analysed and it complies with the specification. Standard pharmaceutical analysis must therefore be regularly carried out on pharmaceutical products before marketing so as to ensure good health, safety, elimination of sub-standard drugs and prevention of over- or under-dosage, which may further affect or cause damage to the health of the users. Consumer's choice of generics should therefore be based on the analytical results (assay results, bio-pharmaceutical results, and statistical results) of the product and the projected bioequivalence.
\end{abstract}

Keywords: Drug assay, pharmaceutical analysis, pharmaceutical products, qualitative assessment, quantitative assessment.

\section{INTRODUCTION}

Pharmaceutical product is any substance or combination of substances administered to human beings or animals with a view to restoring, correcting or modifying physiological functions and for diagnostic purposes (EU, 2004; Racchi et al., 2016). Drug abuse and drug misuse is a common phenomenon in Nigeria due to chaotic drug distribution channels. It is an important factor that results to mortality, morbidity and loss of public confidence in drugs (Cockburn et al., 2005). However, it is quite unfortunate that there is dearth of statistical information on the pecentage of substandard and counterfeited drugs circulating the market in Nigeria till date. This could probably be because of the fear of the fact that information like this when released to the public affect sales of brandname products. Hence there is need to carry out qualitative and quantitative assessments of these pharmaceutical products, which are consumed by the citizens of Nigeria.

The principal criteria for a quality pharmaceutical product are safety, potency, efficacy, and stability (Yamato et al., 1996). World Health Organization claimed that drug manufacturers must undertake responsibility for the quality of the medicines that they manufacture (WHO, 2007; Dulla 
et al., 2018). Many pharmaceutical products have been reported to be substandard and counterfeit. Drug counterfeiting and production of substandard drug is not only found in developing countries but a global problem (WHO, 2012: Sarker et al., 2016). Substandard and counterfeit drugs are threat for the effective treatment of diseases and highly worsen the quality of life of patients (Sarker et al., 2016).

Cockburn et al. (2005) claimed that about $15 \%$ of all drugs in circulation are believed to be counterfeit, with figures rising to as high as $50 \%$ in some part of Africa and Asia. The drugs which qualities were assessed in this study include: paracetamol (Analgesics), Co-trimoxazole and Metronidazole (antibiotics), cough expectorant syrup, and Blood tonics (haematinics).

The research objective involves carrying out quality assessment of five chosen pharmaceutical products of different brands marketed in Nigeria. This is with a view to determining and comparing the assay, quality, percentage purity, variation in physical and chemical compositions of these different brands of pharmaceutical products from different companies and finally gather analytical data that could be used by consumers to determine whether their choice for using any of these drugs should be based on the brand name, price or on the drug purity and composition.

\section{MATERIALS AND METHODS}

\section{Chemicals}

All reagents and chemicals were of analytical grade or better. The qualitative analysis carried out includes friability test, hardness test, disintegration test, dissolution test, $\mathrm{pH}$, and weight uniformity for tablets; specific gravity, flow rate, $\mathrm{pH}$ and weight per $\mathrm{ml}$ of syrups. The quantitative analysis explored in this study includes percentage purity and drug assay determination using titrimetric, spectrophotometric and high performance liquid chromatographic (HPLC) methods of analysis.

\section{Equipment}

pH meter (Seven Compact Mettler Toledo), Electrical weighing balance (Mettler Toledo, ME204E), Friability tester (VEEGO, VFT-2D), Disintegration test apparatus
(Pure Enterprises, Mumbai 400018), Dissolution rate tester- USP (Electolab EDT- 06T), Centrifuge machine (Uniscope SM112), Shaker (Stuart Flask Shaker SH39), Shimadzu digital UV-VIS Spectrophotometer (UV- 1800) and HPLC (Agilent 1100 series) with HYERSIL/ODSCI8, $4.6 \times 2500 \mathrm{~mm} 5 \mu$ column.

\section{Sample collection and preservation}

Sixteen different samples of five pharmaceutical products from different manufacturers commonly used in Nigeria were collected in their sealed form from the manufacturers. The products collected were three brands of Cotrimoxazole tablets, three brands of Metronidazole tablets, three brands of cough expectorants, three brands of Analgesics and four brands of Blood tonics. After collection, prior to analysis, the samples were kept in a cool dry place, as there was no special preservation method for the sample.

However, detailed information of the drugs investigated is presented in Table 1. It includes the drugs/brand codes, active ingredients, manufacturer code, batch number, manufactured date and expiry date.

\section{Bio-pharmaceutical analysis}

The biopharmaceutical procedures were adapted from British or United State pharmacopoeias, except otherwise stated

\section{Preliminary tests analysis}

The preliminary tests: $\mathrm{pH}$, specific gravity, weight per $\mathrm{ml}$ and flow rate were determined by using standard methods.

\section{(a) Weight uniformity test}

Standard method was used for the procedure (Gupta and Saini, 2009; King and Schwarz, 1985; Indian Pharmacopoeia, 1996). 20 tablets from each sample batch were selected randomly and accurately weighed individually with an electronic weighing balance and the average weight of the tablets was calculated as follows:

$$
\text { Weight variation }(\%)=\frac{\text { Individual weight of tablets }- \text { Average weight of tablets }}{\text { Average weight of tablets }} \times 100
$$

\section{(b) Dissolution test}

The dissolution test was performed using spectrophotometric technique and results were calculated in percentage (\%). Solid drugs (Metronidazole and
Paracetamol tablets) were subjected to this test using Shimadzu digital UV-Vis Spectrophotometer at specific wavelength for each drug. Dissolution rate for both Metronidazole and Paracetamol were calculated using: 


$$
\text { Dissolution rate }=\frac{\text { Absorbance from test } \times \text { weight of standard }(\mathrm{mg}) \times 2 \times 50 \times 900 \mathrm{~mL} \times 100}{\text { Absorbance of standard } \times 100 \mathrm{~mL} \times 50 \times 2 \times \text { Claim }(\mathrm{mg})}
$$

Table 1. Summary of the pharmaceutical products and brands investigated.

\begin{tabular}{|c|c|c|c|c|c|c|}
\hline $\mathbf{S} / \mathbf{N}$ & Drugs/Brand codes & Active ingredient(s) & $\begin{array}{l}\text { Manufacturer } \\
\text { code }\end{array}$ & $\begin{array}{l}\text { Batch } \\
\text { number }\end{array}$ & $\begin{array}{l}\text { Date of } \\
\text { manufacture }\end{array}$ & Expiry date \\
\hline \multicolumn{7}{|c|}{ Co-trimoxazole tablet } \\
\hline 01 & $\mathrm{VBCT}_{1}$ & $\begin{array}{l}\text { Sulphamethoxazole } \\
\text { Trimethoprim }\end{array}$ & VBTCS & T64713 & July 2013 & June 2018 \\
\hline 02 & $\mathrm{EMCT}_{2}$ & $\begin{array}{l}\text { Sulphamethoxazole } \\
\text { Trimethoprim }\end{array}$ & EMPHM & $1014 \mathrm{~W}$ & February 2017 & February 2020 \\
\hline 03 & $\mathrm{SKCT}_{3}$ & $\begin{array}{l}\text { Sulphamethoxazole } \\
\text { Trimethoprim }\end{array}$ & SKPHM & 1674 & October 2016 & October 2021 \\
\hline \multicolumn{7}{|c|}{ Metronidazole tablet } \\
\hline 04 & $\mathrm{VBMT}_{1}$ & Metronidazole & VBTCS & T19416 & April 2016 & March 2021 \\
\hline 05 & $\mathrm{MBMT}_{2}$ & Metronidazole & MABAK & R160485 & April 2016 & March 2021 \\
\hline 06 & $\mathrm{SKMT}_{3}$ & Metronidazole & SKPHM & 4216 & September 2016 & September 2021 \\
\hline \multicolumn{7}{|c|}{ Cough expectorant } \\
\hline 07 & $\mathrm{VBCE}_{1}$ & $\begin{array}{l}\text { Diphenhydramine } \mathrm{HCl} \\
\text { Ammonium Chloride } \\
\text { Sodium citrate }\end{array}$ & VBTCS & L9317 & March 2017 & February 2019 \\
\hline 08 & $\mathrm{FMCE}_{3}$ & $\begin{array}{l}\text { Diphenhydramine } \mathrm{HCl} \\
\text { Ammonium Chloride } \\
\text { Sodium citrate }\end{array}$ & FARMY & 60610 & June 2016 & May 2018 \\
\hline 09 & $\mathrm{TYCE}_{3}$ & $\begin{array}{l}\text { Diphenhydramine } \mathrm{HCl} \\
\text { Ammonium Chloride } \\
\text { Sodium citrate }\end{array}$ & TYPHM & TCE 87 & July 2016 & June 2018 \\
\hline \multicolumn{7}{|c|}{ Analgesics } \\
\hline 10 & $\mathrm{VBPC}_{1}$ & Acataminophen & VBTCS & T14316 & March 2016 & February 2021 \\
\hline 11 & $\mathrm{MBPC}_{2}$ & Acataminophen & MABAK & A170169 & February 2017 & January 2022 \\
\hline 12 & $\mathrm{EMPC}_{3}$ & Acataminophen & EMPHM & $1374 \mathrm{~W}$ & March 2017 & March 2022 \\
\hline \multicolumn{7}{|c|}{ Blood tonic } \\
\hline 13 & $\mathrm{VBFT}_{1}$ & $\begin{array}{l}\text { Ferric Ammonium Citrtate } \\
\text { Thiamine (Vitamin } B_{1} \\
\text { Pyridoxine (Vitamin } B_{6}\end{array}$ & VBTCS & L3417 & April 2017 & March 2019 \\
\hline 14 & $\mathrm{FMMT}_{2}$ & $\begin{array}{l}\text { Ferric Ammonium Citrtate } \\
\text { Thiamine (Vitamin } B_{1} \\
\text { Pyridoxine (Vitamin } B_{6}\end{array}$ & FARMY & 4616 & June 2016 & May 2018 \\
\hline 15 & $\mathrm{FMLT}_{3}$ & Ferric Ammonium Citrtate & FARMY & 6916 & September 2016 & August 2018 \\
\hline 16 & $\mathrm{TYBT}_{4}$ & $\begin{array}{l}\text { Ferric Ammonium Citrtate } \\
\text { Thiamine (Vitamin } B_{1} \\
\text { Pyridoxine (Vitamin } B_{6}\end{array}$ & TYPHM & BBS220 & December 2016 & November 2018 \\
\hline
\end{tabular}


Metronidazole tablet: The dissolution rates of the active content from the tablets were determined using dissolution apparatus. The dissolution medium was $900 \mathrm{~mL}$ of $0.1 \mathrm{~N}$ $\mathrm{HCl}$ at $37.0 \pm 0.5^{\circ} \mathrm{C}$. One tablet each was dropped into six jars containing $0.1 \mathrm{~N} \mathrm{HCl}$ and the paddles were caused to rotate at a rotational speed of $100 \mathrm{rpm}$ for $60 \mathrm{~min} .5 \mathrm{~mL}$ of the sample was withdrawn and centrifuged. The amount of Metronidazole dissolved after $60 \mathrm{~min}$ was determined using Shimadzu digital UV-Vis Spectrophotometer by taking absorbance at the wavelength of maximum absorbance at about $278 \mathrm{~nm}$ in comparison with a standard Metronidazole solution in the same medium $(0.1 \mathrm{~N} \mathrm{HCl})$. By measuring the absorbance, the percentage (\%) of drug dissolved was calculated.

Paracetamol tablet: The dissolution test was performed by using Dissolution Tester-USP. The dissolution medium was $900 \mathrm{ml}$ of phosphate buffer $(\mathrm{pH} 5.8)$ at $37 \pm 0.5^{\circ} \mathrm{C}$. One tablet each was dropped into six jars containing the dissolution medium and the paddles were caused to rotate at a rotational speed of $50 \mathrm{rpm}$ for $30 \mathrm{~min}$. After $30 \mathrm{~min}, 5$ $\mathrm{mL}$ of the sample solution was withdrawn and diluted with the same dissolution medium and the amount of dissolved paracetamol was determined using Shimadzu digital UVVis Spectrophotometer by taking absorbance at the wavelength of maximum absorbance at about $243 \mathrm{~nm}$ in comparison with a standard (USP, 2014). By measuring the absorbance, the percentage (\%) of drug dissolved was calculated.

\section{(c) Disintegration test}

A disintegration apparatus containing six glass tubes was used for the purpose. The disintegration test was performed as USP to determine the time taken for the solid dosage forms to disintegrate in distilled water at $37^{\circ} \mathrm{C}$. One tablet (each) of the drug sample to be analysed was placed in each tube and the basket rack is positioned in a $1 \mathrm{~L}$ beaker containing $500 \mathrm{~mL}$ distilled water at $37 \pm 2^{\circ} \mathrm{C}$ temperature. The instrument was operated with a motor driven device with 28 to $32 \mathrm{cycle} / \mathrm{min}$ frequency. The individual time taken for all the tablet particles in each unit to pass through the mesh was recorded. Average of the time for the six tablets was taken as the disintegration time. For uncoated tablets the disintegration time limit is $15 \mathrm{~min}$ (Musa et al., 2011; Gupta and Vishal, 2013).

\section{(d) Friability test}

10 tablets were randomly selected and weighed $\left(W_{1}\right)$. The weighed tablets were placed in a friability machine operated at $100 \mathrm{rpm}$ for $4 \mathrm{~min}$. The tablets were weighed again (W2) (Ansel et al., 1995; USP, 2014) and the percentage loss was then calculated by using:

Percentage loss $=\frac{\text { Initial weight }(\mathrm{W} 1)-\text { final weight }(\mathrm{W} 2)}{\text { Initial weight }(\mathrm{W} 1)} \times 100$.
The official permissible limit for friability is $1 \%$.

\section{(e) Hardness test:}

This shows the ability of a tablet to withstand mechanical shocks during handling in manufacturing, packaging and shipping (Khar et al., 2013). Standard method was used for this test. One sampled tablet was placed on the hardness tester and the hardness tester was reset to its calibration figure $(0.00)$ by pressing the reset key on the tester. The load was applied along the radial axis of the tablet. The weight or load required for breaking the tablet was noted down. This procedure was repeated ten times. The average was taken and was converted from kilo pound to $\mathrm{kgf} / \mathrm{cm}$.

\section{Assay determination}

\section{Co-trimoxazole tablet}

Preparation of reference standard: Weigh sulfamethoxazole and Trimethoprim equivalent to $0.640 \mathrm{~g}$ and $0.128 \mathrm{~g}$ respectively into a $100 \mathrm{ml}$ volumetric flask, 70 $\mathrm{mL}$ of methanol was added and was shaken mechanically for $15 \mathrm{~min} .25 \mathrm{~mL}$ of the resulting solution was diluted to $50 \mathrm{~mL}$ with methanol and $25 \mathrm{~mL}$ of the diluted solution was further diluted to $100 \mathrm{~mL}$ with the prepared mobile phase.

Preparation of mobile phase: Mix $1400 \mathrm{~mL}$ of distilled water with $400 \mathrm{~mL}$ of acetonitrile and $2 \mathrm{~mL}$ of triethylamine in a $2000 \mathrm{~mL}$ volumetric flask. The resulting solution was allowed to equilibrate to room temperature and adjusted with dilute glacial acetic acid to a $\mathrm{pH}$ of 5.8 - 6.0 and further diluted to volume with distilled water.

Assay determination: High Performance Liquid Chromatography (HPLC) was used for the assay determination. It is based on the peak area of the test in comparison with the peak area of the standard of the solution. 20 tablets of the sample were randomly selected and smoothly powdered. Weighed quantity of the powder equivalent to $0.160 \mathrm{~g}$ of Sulfamethoxazole was accurately transferred into $50 \mathrm{ml}$ volumetric flask. $25 \mathrm{~mL}$ of methanol was added. The flask was shaken mechanically for 15 min and further diluted to mark with the same solvent. $5 \mathrm{~mL}$ of the resulting solution was centrifuge for about $2 \mathrm{~min}$ and $2.5 \mathrm{~mL}$ of the supernatant was diluted to $50 \mathrm{~mL}$ with the mobile phase. The HPLC machine was operated and equal volume (about $20 \mu \mathrm{L}$ ) of the standard and assay preparations were separately injected into the column. The chromatogram was recorded and the peak response for the major peak was measured. Percentage yields for Sulfamethoxazole and Trimethoprim were calculated using: 


$$
\text { Percentage yields }=\frac{\text { Peak area of sample } \times \text { Weight of std } \times 25 \times 2.5 \times 50 \times 50 \times \text { Average Wt of tablets } \times 100}{\text { Peak area of standard } \times 100 \times 50 \times 50 \times 2.5 \times \text { Weight of sample } \times \text { Label claim }}
$$

The amount (mg) for Sulfamethoxazole and Trimethoprim were calculated using

Amount $(\mathrm{mg})=\frac{\text { Percentage yield }}{100} \times$ Claim

\section{Metronidazole tablet}

Assay determination: Spectrophotometric method was used for this study. 20 tablets were selected randomly and grounded to powder. Approximately $50 \mathrm{mg}$ of Metronidazole was accurately weighed into a $200 \mathrm{ml}$ volumetric flask. $70 \mathrm{~mL}$ of $0.1 \mathrm{M} \mathrm{HCl}$ (reagent solution) was added and shaken mechanically for $15 \mathrm{~min}$. The $200 \mathrm{~mL}$ volumetric flask was filled to mark with $0.1 \mathrm{M} \mathrm{HCl}$ and was centrifuged for $15 \mathrm{~min} .5 \mathrm{~mL}$ of the supernatant was diluted to $100 \mathrm{~mL}$ with $0.1 \mathrm{M} \mathrm{HCl}$. The absorbance of the final solution was measured at $277 \mathrm{~nm}$ and the value of extinction of $1 \%$ solution using $1 \mathrm{~cm}$ cell $\left(E_{1} \%\right)$ and theoretical concentration (T.C) was taken as 380 and $0.00125 \%$ respectively. The Metronidazole content in each sample was calculated using:

Weight used $=\frac{\text { Ave. } \text { weight of } 20 \text { tablets } \times \text { Equivalent weight }}{\text { Label amount }}$

Percentage Yield $=\frac{\text { Absorbance of Sample }}{(\text { E1\%) } \times \text { T.C }} \times 100$

The potency of Metronidazole content is calculated as above

\section{Cough expectorant syrup}

The three active ingredients (Diphenhydramine

$$
\text { Potency }=\frac{\text { Peak area of Sample } \times \text { Weight of standard } \times 5 \times 50 \times 5 \times \text { Weight } / \mathrm{mL}}{\text { Peak area of standard } \times 25 \times 50 \times \text { Weight of sample }}
$$

Percentage yield $=\frac{\text { Concentration observed }(\mathrm{mg} / \mathrm{mL})}{\text { Claim }\{\mathrm{mg} / \mathrm{mL}\}}$

$\%$ yield $=\frac{\text { Vol. of AgN03 used } \times \text { mL equvalent } \times \text { factor } \times 100}{\text { Equivalent weight of ammonium chloride }}$

\section{(ii) Ammonium Chloride by titrimetry}

Ammonium Chloride concentration in the Cough syrup was determined by titrimetric method. $1 \mathrm{~g}$ of the syrup was accurately weighed into $50 \mathrm{~mL}$ beaker and $20 \mathrm{~mL}$ of $\mathrm{CO}_{2}$ free distilled water was added. $0.4 \mathrm{~mL}$ of potassium chromate solution (indicator) was added. The solution was titrated against $0.1 \mathrm{M} \mathrm{AgNO}_{3}$. The content of Ammonium chloride in each sample is calculated using:
Hydrochloride, Ammonium Chloride and Sodium Citrate) in this drug were determined using High Performance Liquid Chromatography (HPLC) and titrimetry

\section{(i) Diphenylhydramine Hydrochloride by HPLC}

Preparation of mobile phase: $400 \mathrm{~mL}$ of acetonitrile was added into a $1000 \mathrm{~mL}$ volumetric flask containing $500 \mathrm{~mL}$ distilled water. Thereafter, $5 \mathrm{~mL}$ of triethylamine was added and mixed thoroughly. The $\mathrm{pH}$ of the resulting solution was adjusted with glacial acetic acid to 6.00 and further diluted to $1000 \mathrm{ml}$ with distilled water. The $\mathrm{pH}$ was checked and further adjusted with triethylamine since it was not at 6.00 and was mixed and transferred to the reagent bottle.

Assay determination: $5 \mathrm{ml}$ of the test sample was accurately measured into a $50 \mathrm{~mL}$ volumetric flask and 20 $\mathrm{mL}$ of the mobile phase was added and shaken for about $5 \mathrm{~min}$ and was further diluted to volume with the same mobile phase. HPLC machine was operated and volume about $40 \mu \mathrm{L}$ of the standard and the assay preparation was injected separately into the column at $220 \mathrm{~nm}$ detector using Zorbax SB - C18, $4.6 \times 75 \mathrm{~mm} / 150 \mathrm{~mm}, 3.5 \mu$.

Preparation of standard: $75 \mathrm{mg}$ of diphenhydramine reference standard was weighed into a $25 \mathrm{~mL}$ volumetric flask, $10 \mathrm{~mL}$ of mobile phase was added and shaken until it was completely dissolved and was diluted with the mobile phase. $5 \mathrm{~mL}$ of the resulting solution was further diluted to $50 \mathrm{~mL}$ with the mobile phase. The potency (milligram) of diphenhydramine $\mathrm{HCl}$ observed in each sample is calculated using: 
Percentage yield $=\frac{\text { Titre value }- \text { titre value of blank } \times \text { mL equivalent } \times \text { factor } \times 100}{146.53}$

\section{Paracetamol tablet}

20 Paracetamol tablets were selected randomly and grounded to fine powder. $0.15 \mathrm{~g}$ of the powder was weighed into a $200 \mathrm{~mL}$ volumetric flask and $50 \mathrm{~mL}$ of 0.1 $\mathrm{M} \mathrm{NaOH}$ and distilled water were added. The solution was shaken mechanically for 15 min, made up to mark with distilled water and filtered. $10 \mathrm{~mL}$ of the filtrate was pipetted into a $100 \mathrm{~mL}$ volumetric flask. $10 \mathrm{~mL}$ of the resulting solution and $10 \mathrm{~mL}$ of $0.1 \mathrm{M} \mathrm{NaOH}$ was pipetted into another $100 \mathrm{~mL}$ volumetric flask and made up with distilled water. The absorbance of the final solution was measured at $257 \mathrm{~nm}$ taking 715 as the extinction of $1 \%$ solution using $1 \mathrm{~cm}$ cell $\left(E_{1} \%\right)$ and and $0.00075 \mathrm{w} / \mathrm{v}$ as the theoretical value. The content of acetaminophen in the specified samples is calculated using:

Percentage yield $=\frac{\text { Absorption of Sample }}{\text { E1\% } \times \text { Theoretical Conc. }} \times 100$

\section{Blood tonic}

Assay of the active ingredients; Ferric Ammonium Citrate, Thiamine (Vitamin $B_{1}$ ) and Pyridoxine (Vitamin $B_{6}$ ) was determined using spectrophotometric and high performance liquid chromatographic analysis were used for this study.

\section{(i) Ferric Ammonium Citrate}

Preparation of standard: $54 \mathrm{mg}$ of Ferric ammonium citrate was weighed accurately into a $100 \mathrm{~mL}$ volumetric flask, $20 \mathrm{~mL}$ distilled water was added and shaken to dissolve. This was made up to volume with distilled water. The test sample was prepared by pipetting $5 \mathrm{~mL}$ of ferric ammonium citrate into a $100 \mathrm{~mL}$ volumetric flask containing distilled water. This was made up to volume and further shaken very well for a homogenous mixture.

Assay determination: $3 \mathrm{~mL}$ of the standard and sample solution were pipetted into two different volumetric flasks. $7 \mathrm{~mL}$ distilled water, $2 \mathrm{~mL}$ of $20 \% \mathrm{w} / \mathrm{v}$ citric acid solution, $0.6 \mathrm{~mL}$ of $5 \% \mathrm{w} / \mathrm{v}$ thioglycolic acid solution were added and made up to volume with dilute ammonia solution and was shaken very well. The extinction of the solution was measured using UV Spectrophotometer taking the wavelength at $550 \mathrm{~nm}$ using distilled water as blank. The potency or content of ferric ammonium citrate in the sample is calculated using:

Percentage Yield $=\frac{\text { Absorption of test }}{\text { Absorption of standard }} \times 100$

\section{(ii) Thiamine (Vitamin $\mathrm{B}_{1}$ ) and Pyridoxine (Vitamin $\mathrm{B}_{6}$ )}

Preparation of mobile phase: $720 \mathrm{~mL}$ of distilled water, $270 \mathrm{~mL}$ of methanol and $10 \mathrm{~mL}$ of glacial acetic acid were accurately measured into a $1000 \mathrm{~mL}$ volumetric flask. 1.40 $\mathrm{g}$ of sodium 1-hexane sulphamate was added into the solution and then shaken thoroughly for it to dissolve in the solution.

Preparation of standard: $0.05 \mathrm{~g}$ of thiamine $\mathrm{HCl}$ and pyridoxine $\mathrm{HCl}$ was accurately transferred into $100 \mathrm{~mL}$ volumetric flask. $60 \mathrm{~mL}$ of diluting solution (mixture of 940 $\mathrm{mL}$ of distilled water, $50 \mathrm{ml}$ of acetonitrile and $10 \mathrm{~mL}$ of glacial acetic acid) was added and shaken mechanically for $15 \mathrm{~min}$. The solution was diluted to volume with the diluting solution and was mixed. $4 \mathrm{~mL}$ of the resulting solution was further diluted to $100 \mathrm{~mL}$ with the diluting solution.

Assay determination: $5 \mathrm{~mL}$ of the syrup was accurately transferred into $100 \mathrm{~mL}$ volumetric flask and $5 \mathrm{~mL}$ of the diluting solution was added and the solution was shaken mechanically for $15 \mathrm{~min}$. Equal volume of the standard and assay prepared was separately injected into the HPLC column and the chromatogram was recorded and the peak response for the major peak was measured.

NOTE: Overage amounts of the ingredients were included to compensate for losses due to degradation during products life.

$\%$ yield $=\frac{\text { Peak area of Spl } \times \text { Wt of std } \times 2 \times 100 \times 5 \times 100}{\text { Peak area of std } \times 50 \times 50 \times 50 \times \text { Wt of Std } \times 4}$

\section{Statistical analysis}

In order to have a fair appraisal of the agreement and variability amongst the data for the different groups of drugs analysed, Coefficient of Variation (CV) was used to compare differences between the weights per tablet of the different drugs. CV was calculated using the formula:

$$
\mathrm{CV}=\frac{\mathrm{S} . \mathrm{D}}{\text { Mean }} \times 100
$$

Where S.D is standard deviation.

\section{RESULTS}

The results of the analytical test are presented in Tables $2,3,4,5$ and 6 . Table 2 show the results from preliminary tests ( $\mathrm{pH}$, weight per ml, specific gravity and flow rates) of the liquid drug samples. Comparison of weight uniformity 
Table 2. Preliminary test results on some pharmaceutical liquid products of different brands investigated.

\begin{tabular}{llcccc}
\hline \multirow{2}{*}{ Tablets } & \multirow{2}{*}{ Sample } & \multicolumn{4}{c}{ Test } \\
\cline { 3 - 6 } & & $\mathbf{p H}$ & Specific gravity & Weight/ml & Flow rate/min \\
\hline 01 & VBCE $_{1}$ & 5.18 & 1.22 & 1.22 & 6.38 \\
02 & FMCE $_{2}$ & 5.34 & 1.21 & 1.21 & 48.95 \\
03 & TYCE $_{3}$ & 5.57 & 1.14 & 1.22 & 53.28 \\
04 & VBFT $_{1}$ & 5.43 & 1.13 & 1.20 & 40.97 \\
05 & FMMT $_{2}$ & 5.20 & 1.20 & 1.27 & 22.02 \\
06 & FMLT $_{3}$ & 5.24 & 1.23 & 1.22 & 21.67 \\
07 & TYBT $_{4}$ & 5.15 & 1.29 & 1.29 & 21.05 \\
Range & & $5.15-5.57$ & $1.13-1.29$ & $1.20-1.29$ & $6.38-53-28$ \\
\hline
\end{tabular}

(\%), mean weight (g), standard deviation (SD) and coefficient of variation (CV) of the tablets of different brands of tablets $(n=20)$ are presented in Table 3. The dissolution test results (\%) for tablets of different brands investigated using spectrophotometry and appraised using British Pharmacopea (BP) specification of 70 to $110 \%$ range are shown in Table 4. Table 5 show the disintegration time (min), friability (\%) and hardness (\%) test results for tablets of different brands investigated compared with specification. And Table 6 show the assay results of the pharmaceutical products investigated.

\section{DISCUSSION}

\section{Preliminary test and other physico-chemical results}

The results on $\mathrm{pH}$, weight per $\mathrm{ml}$, specific gravity and flow rates of the liquid drug samples are presented in Table 2. $\mathrm{pH}$ values ranged from 5.15 to 5.57 , which indicated that all the samples were all weakly acidic. The weights per $\mathrm{ml}$ as well as specific gravities of the samples were within the same range, with the weight per $\mathrm{ml}$ ranging from 1.20 to 1.29 and specific gravity ranging from 1.13 to 1.29 . The flow rate of the samples ranged from 6.38 to 53.3 with $\mathrm{VBCE}_{1}$ and $\mathrm{TYCE}_{3}$ having the least and the fastest flowrate respectively.

Results of weight uniformity (Table 3 ) for Metronidazole samples (VBMT $1, \mathrm{MBMT}_{2}$ and $\mathrm{SKMT}_{3}$ ); Analgesic samples $\left(V_{B P C}, M_{1 B P C}\right.$ and $E_{\left.3 P C_{3}\right)}$ and Co-trimoxazole samples $\left(\mathrm{VBCT}_{1}, \mathrm{EMCT}_{2}\right.$ and $\mathrm{SKCT}_{3}$ ) fell within $\pm 5 \%$ permissible for tablets drugs that exceed $250 \mathrm{mg}$ (USP, 2014) and none of them deviated by up to twice the percentage permissible range. The result obtained from statistical analysis showed that there is uniformity in weight for all tablets analyzed and they all met the specification. The coefficient of variation was used to explain weight uniformity of tablets of the different brands (Table 3 ).

The dissolution test results (Table 4) showed that dissolution rates of tablets of different brands investigated ranged between 89.93 to $93.49 \%$ in the order, $\mathrm{MBMT}_{2}<$ $\mathrm{SKMT}_{3}<\mathrm{VBMT}_{1}$ for Metronidazole and $\mathrm{EMPC}_{3}<\mathrm{MBPC}_{2}$
$<\mathrm{VBPC}_{1}$, for Analgesic. All values obtained met the British pharmacopeia specification of 70 to $100 \%$ (BP, 2002).

Table 5 showed the results of disintegration, friability and hardness tests conducted on samples of Cotrimoxazole, Metronidazole and Analgesic. All the samples met the British Pharmacopeia specifications for the tests (BP, 2002). The disintegration times ranged from 5.65 to $6.60 \mathrm{~min}$ for Co-trimoxazole (in the order $\mathrm{VBCT}_{1}<\mathrm{EMCT}_{2}$ $<\mathrm{SKCT}_{3}$ ); 0.45 to $0.60 \mathrm{~min}$ for Metronidazole (in the order $\mathrm{SKMT}_{3}<\mathrm{VBMT}_{1}<\mathrm{MBMT}_{2}$ ) and 0.75 to $4.40 \mathrm{~min}$ for Analgesics (in the order $\mathrm{MBPC}_{2}<\mathrm{VMPC}_{1}<\mathrm{EMPC}_{3}$ ). In the disintegration test, all the tested brands were observed to pass the test as they are all disintegrated within the specification time. It must be noted that the lower the disintegration time, the faster the time of action. For Cotrimoxazole tablet, $\mathrm{VBCT}_{1}$ had the lowest disintegration time and is expected that the absorption will be faster compare to other samples analysed. Generally, Metronidazole disintegrated at a faster rate. SKMT 3 disintegrated faster than other samples and it is expected that the rate of absorption of this sample will be more than other samples (SKMT<VBMT<MBMT). For Analgesics, $\mathrm{MBPC}_{2}$ disintegrated faster and rapidly. Thus, the absorption and the onset of action will be faster than other sample analysed. This, however, may be the reason why people in Nigeria prefer $\mathrm{MBPC}_{2}$ than any other in Nigeria. In Co-trimoxazole samples, VBCT disintegrated faster than other samples in the order VBCT<EMCT $<$ SKCT. Though all the samples comply with the standard as specified in the monographs, sample VBCT will produce rapid absorption and faster onset of action.

Friability test is essential to evaluate the ability of a tablet to withstand abrasion in packing, handling and transporting while hardness indicates the capability of a tablet to withstand mechanical shocks during handling in manufacturing, packaging and shipping. The hardness and friability tests showed that all the samples were within the acceptable specifications of $1 \%$ in the monographs. These qualities of the samples assure the structural integrity of these samples and guarantee their staying on the shelves for years without deformation and their ability 


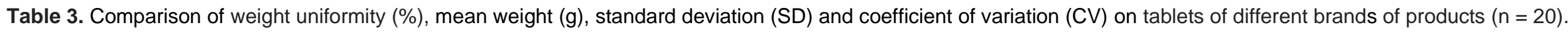

\begin{tabular}{|c|c|c|c|c|c|c|c|c|c|c|c|c|c|c|c|c|c|c|}
\hline \multirow{3}{*}{ Tablets } & \multicolumn{18}{|c|}{ Samples } \\
\hline & \multicolumn{2}{|c|}{$\mathrm{VBCT}_{1}$} & \multicolumn{2}{|c|}{$\mathrm{EMCT}_{2}$} & \multicolumn{2}{|c|}{$\mathrm{SKCT}_{3}$} & \multicolumn{2}{|c|}{ VBMT $_{1}$} & \multicolumn{2}{|c|}{$\mathrm{MBMT}_{2}$} & \multicolumn{2}{|c|}{$\mathrm{SKMT}_{3}$} & \multicolumn{2}{|c|}{ VBPC $_{1}$} & \multicolumn{2}{|c|}{$\mathrm{MBPC}_{2}$} & \multicolumn{2}{|c|}{$\mathrm{EMPC}_{3}$} \\
\hline & $\mathrm{Wt} / \mathrm{g}$ & $\% \operatorname{Dev}$ & $\mathrm{Wt} / \mathrm{g}$ & \%Dev & $W t / g$ & \%Dev & $\mathrm{Wt} / \mathrm{g}$ & $\%$ Dev & $\mathrm{Wt} / \mathrm{g}$ & \%Dev & $\mathrm{Wt} / \mathrm{g}$ & $\% \operatorname{Dev}$ & $\mathrm{Wt} / \mathrm{g}$ & $\% \operatorname{Dev}$ & $\mathrm{Wt} / \mathrm{g}$ & \%Dev & $\mathrm{Wt} / \mathrm{g}$ & \%Dev \\
\hline 01 & 0.5745 & 0.0000 & 0.5271 & -0.0758 & 0.5152 & 3.3293 & 0.4116 & 0.3658 & 0.5023 & -1.2775 & 0.5138 & 3.0485 & 0.5746 & -0.4332 & 0.5637 & -0.2654 & 0.5528 & 0.8575 \\
\hline 02 & 0.5747 & 0.0348 & 0.5316 & 0.7773 & 0.5092 & 2.1260 & 0.4114 & 0.3170 & 0.5177 & 1.7492 & 0.4964 & -0.4412 & 0.5754 & -0.2946 & 0.5612 & -0.7077 & 0.5502 & 0.3831 \\
\hline 03 & 0.5812 & 1.666 & 0.5317 & 0.7962 & 0.4974 & -0.2407 & 0.4028 & -1.7800 & 0.5008 & -1.5723 & 0.4992 & 0.1203 & 0.5685 & -1.4902 & 0.5555 & -1.7162 & 0.5465 & -0.2919 \\
\hline 04 & 0.5746 & 0.0174 & 0.5351 & 1.4408 & 0.4863 & -2.4669 & 0.4112 & 0.2682 & 0.5094 & 0.1179 & 0.5064 & 1.5643 & 0.5667 & -1.8021 & 0.5668 & 0.2831 & 0.5445 & -0.6568 \\
\hline 05 & 0.5796 & 0.8877 & 0.5361 & -2.1611 & 0.4935 & -1.0229 & 0.4017 & -2.0483 & 0.5175 & 1.7099 & 0.4983 & -0.0616 & 0.5742 & -0.5025 & 0.5694 & 0.7410 & 0.5471 & -0.1824 \\
\hline 06 & 0.5693 & -0.9051 & 0.5312 & 0.7014 & 0.4971 & -0.3008 & 0.4052 & -1.1948 & 0.5114 & 0.5110 & 0.4883 & -2.0657 & 0.5773 & 0.0347 & 0.5657 & 0.0885 & 0.5505 & 0.4379 \\
\hline 07 & 0.5698 & -0.8181 & 0.5223 & -0.9858 & 0.5130 & 2.8881 & 0.4009 & -2.2434 & 0.5027 & -1.1989 & 0.4871 & -2.3065 & 0.5739 & -0.5545 & 0.5743 & 1.6100 & 0.5494 & 0.2372 \\
\hline 08 & 0.5744 & -0.0174 & 0.5314 & 0.7393 & 0.5093 & 2.1460 & 0.4136 & 1.2680 & 0.5045 & -0.8451 & 0.4894 & -1.8452 & 0.5735 & -0.6238 & 0.5625 & -0.4771 & 0.5450 & -0.5656 \\
\hline 09 & 0.5804 & 1.0269 & 0.5337 & 1.1754 & 0.4874 & -2.2463 & 0.4153 & 0.2682 & 0.5114 & 0.5110 & 0.4977 & -0.2195 & 0.5663 & -1.8714 & 0.5744 & 1.6277 & 0.5428 & -0.9670 \\
\hline 10 & 0.5808 & 1.1140 & 0.5327 & 0.9858 & 0.4821 & -3.3093 & 0.4117 & 0.3901 & 0.5055 & 0.6456 & 0.4926 & -0.1805 & 0.5658 & -1.9581 & 0.5666 & 0.2477 & 0.5570 & 1.6238 \\
\hline 11 & 0.5752 & 0.1218 & 0.5245 & -0.5687 & 0.4963 & -0.4613 & 0.4162 & 1.4874 & 0.5048 & -0.7862 & 0.5174 & 3.7706 & 0.5982 & 3.6562 & 0.5705 & 0.9377 & 0.5510 & 0.5291 \\
\hline 12 & 0.5730 & -0.2611 & 0.5122 & -2.9004 & 0.4846 & -2.8079 & 0.4133 & 0.7803 & 0.5103 & 0.2948 & 0.5015 & 0.5816 & 0.5788 & 0.2946 & 0.5758 & 1.8754 & 0.5502 & 0.3831 \\
\hline 13 & 0.5821 & 1.3229 & 0.5314 & 0.7393 & 0.4925 & -1.2234 & 0.4139 & 0.9266 & 0.5193 & -1.3758 & 0.4968 & 0.3610 & 0.5685 & -0.4963 & 0.5574 & -1.3800 & 0.5346 & -2.4631 \\
\hline 14 & 0.5714 & -0.5396 & 0.5284 & 0.1706 & 0.5208 & 4.4525 & 0.4127 & 0.6340 & 0.5018 & -3.4395 & 0.5104 & 2.3666 & 0.5799 & 0.4852 & 0.5651 & -0.0177 & 0.5501 & 0.3649 \\
\hline 15 & 0.5799 & 0.9399 & 0.5345 & 1.3270 & 0.5113 & 2.5471 & 0.4103 & 0.0488 & 0.4913 & -1.4151 & 0.4952 & -0.6819 & 0.5787 & 0.2772 & 0.5544 & -1.9108 & 0.5505 & 0.4379 \\
\hline 16 & 0.5808 & 1.0966 & 0.5326 & 0.9668 & 0.4913 & -1.4641 & 0.4040 & -1.4874 & 0.5016 & -0.5699 & 0.4982 & -0.0802 & 0.5734 & -0.6411 & 0.5587 & -1.1500 & 0.5523 & 0.7663 \\
\hline 17 & 0.5818 & 1.2707 & 0.5123 & -2.8815 & 0.4822 & -3.2892 & 0.4152 & 1.2436 & 0.5059 & 1.6509 & 0.4973 & -0.2607 & 0.5756 & -0.2599 & 0.5793 & 2.4947 & 0.5486 & 0.0912 \\
\hline 18 & 0.5695 & -1.2707 & 0.5245 & -0.5687 & 0.5263 & 3.5499 & 0.4130 & 0.7071 & 0.5172 & 1.8278 & 0.4892 & -1.8853 & 0.5799 & 0.4852 & 0.5440 & -3.7509 & 0.5592 & 2.0252 \\
\hline 19 & 0.5804 & -0.8703 & 0.5291 & 1.1564 & 0.4931 & -1.1030 & 0.4124 & 0.5608 & 0.5181 & 2.8302 & 0.4963 & -0.4613 & 0.5769 & -0.0347 & 0.5615 & -0.6546 & 0.5431 & -0.9122 \\
\hline 20 & 0.5672 & 1.0270 & 0.5241 & -0.6445 & 0.4924 & -1.2435 & 0.4048 & -1.2924 & 0.5232 & 2.0637 & 0.5003 & 0.3410 & 0.5769 & -0.0520 & 0.5768 & 2.0524 & 0.5447 & -0.6203 \\
\hline TW (g) & 11.4943 & & 10.5553 & & 9.9690 & & 8.2099 & & 10.1760 & & 9.9737 & & 11.5075 & & 11.3142 & & 10.8677 & \\
\hline Mean (g) & 0.5745 & & 0.5275 & & 0.4986 & & 0.4101 & & 0.5088 & & 0.4986 & & 0.5771 & & 0.5652 & & 0.5481 & \\
\hline S.D & 0.0004 & & 0.0022 & & 0.0001 & & 0.0000 & & 0.0011 & & 0.0001 & & 0.0001 & & 0.0001 & & 0.0000 & \\
\hline CV (\%) & 0.07 & & 0.42 & & 0.02 & & 0.00 & & 0.22 & & 0.02 & & 0.02 & & 0.02 & & 0.00 & \\
\hline
\end{tabular}

NB: TW= Total weight

to withstand handling as well as resistance to mechanical shock during transportation.

These indicated that the disintegration, friablity and hardness test results were within accepted standards of $0.05 \mathrm{Kgf} / \mathrm{cm}^{2}(\mathrm{~min}) ; 1 \%$ and $15 \mathrm{~min}$ (max) respectively (BP, 2002; USP, 2014).

\section{Drug assay results}

Table 6 presents the results of percentage purity and drug assay determination on all the five groups of drug samples analysed. Titrimetric, spectrophotometric and high performance liquid chromatographic (HPLC) methods were used for the analysis.

In this assessment study, the potencies of the active ingredients in the samples, Metronidazole $\left(\mathrm{VBMT}_{1}, \mathrm{MBMT}_{2}\right.$ and $\left.\mathrm{SKMT}_{3}\right)$, Analgesic $\left(\mathrm{VBPC}_{1}\right.$, $\mathrm{MBPC}_{2}$ and $\mathrm{EMPC}_{3}$ ), Co-trimoxazole (VBCT 1 , $\mathrm{EMCT}_{2}$ and $\left.\mathrm{SKCT}_{3}\right)$, Cough expectorants $\left(\mathrm{VBCE}_{1}\right.$, $\mathrm{TYCE}_{3}$ and $\mathrm{FMCE}_{2}$ ) and Blood tonic (VBFT $\mathrm{FMMT}_{2}, \mathrm{FMLT}_{3}$, and $\mathrm{TYBT}_{4}$ ), were determined. Accordiing to British Pharmacopeia (2002), the assay specification for active ingredients in Cotrimoxazole, Metronidazole, Analgesics are 93 -
102, 98 - 102, 95 - 105\% respectively. For Cough expectorants which contains ammonium chloride, diphenhydramine $\mathrm{HCl}$ and sodium citrate, the specifications are $94-106,90-110 \%$ and $95-$ $106 \%$ respectively. Also, for Blood tonic, which contains ammonium citrate, thiamine (Vitamin $\mathrm{B}_{1}$ ) and pyridoxine (Vitamin $\mathrm{B}_{6}$ ), the specifications are $95.5-150,110-150$ and $110-150 \%$ respectively. Experimental results showed the potencies of sulphamethoxazole and trimethoprim in Cotrimoxazole samples to be 96.10 and $98.90 \%$ in $\mathrm{VBCT}_{1} ; 94.37$ and $94.37 \%$ in $\mathrm{EMCT}_{2}$ and 96.28 and $96.45 \%$ in $\mathrm{SKCT}_{3}$. For Metronidazole samples, the 
Table 4. Dissolution test results (\%) for tablets of different brands investigated using spectrophotometry and data quality appraised using British Pharmacopea (BP) specification of $70-110 \%$ range.

\begin{tabular}{llcl}
\hline $\mathbf{S} / \mathbf{N}$ & Brand code & Dissolution (\%) & Remark \\
\hline 01 & $\mathrm{VBMT}_{1}$ & 93.49 & Passed \\
02 & $\mathrm{MBMT}_{2}$ & 91.03 & Passed \\
03 & $\mathrm{SKMT}_{3}$ & 91.48 & Passed \\
04 & $\mathrm{VBPC}_{1}$ & 92.64 & Passed \\
05 & $\mathrm{MBPC}_{2}$ & 91.04 & Passed \\
06 & $\mathrm{EMPC}_{3}$ & 89.93 & Passed \\
Range & & $89.93-93.49$ & \\
\hline
\end{tabular}

Table 5. Disintegration time (min), friability (\%) and hardness (\%) test results for tablets of different brands investigated compared with specification.

\begin{tabular}{llcccl}
\hline $\mathbf{S} / \mathbf{N}$ & Brand code & Disintegration time $(\mathbf{m i n})$ & Friability $(\%)$ & Hardness $\left(\mathbf{K g f} / \mathbf{c m}^{2}\right)$ & Remark \\
\hline 01 & $\mathrm{VBCT}_{1}$ & 5.65 & 0.73 & 0.1554 & Passed \\
02 & $\mathrm{EMCT}_{2}$ & 5.80 & 0.81 & 0.1481 & Passed \\
03 & $\mathrm{SKCT}_{3}$ & 6.60 & 0.87 & 0.1911 & Passed \\
04 & $\mathrm{VBMT}_{1}$ & 0.60 & 0.70 & 0.0518 & Passed \\
05 & $\mathrm{MBMT}_{2}$ & 0.63 & 0.51 & 0.075 & Passed \\
06 & $\mathrm{SKMT}_{3}$ & 0.45 & 0.43 & 0.0980 & Passed \\
07 & $\mathrm{VBPC}_{1}$ & 3.85 & 0.64 & 0.1182 & Passed \\
08 & $\mathrm{MBPC}_{2}$ & 0.75 & 0.56 & 0.1136 & Passed \\
09 & $\mathrm{EMPC}_{3}$ & 4.40 & 0.76 & 0.1094 & Passed \\
Range & & $0.60-6.60$ & $0.43-0.87$ & $0.0518-0.1911$ & \\
\multicolumn{2}{l}{ Specifications } & $0.05 \mathrm{Kg} / \mathrm{cm}^{2}(\mathrm{~min})$ & $1 \% \mathrm{~min}$ & $<15 \mathrm{~min}(\mathrm{max})$ & \\
\hline
\end{tabular}

potency of Metronidazole in $\mathrm{VBMT}_{1}, \mathrm{MBMT}_{2}$ and $\mathrm{SKMT}_{3}$ was $100.00,101.89$ and $99.57 \%$ respectively. Similarly, the potencies of diphenhydramine $\mathrm{HCl}$, ammonium chloride and sodium citrate in Cough expectorant samples were 99.21, 99.98 and $101.53 \%$ for $\mathrm{VBCE}_{1} ; 105.00$, 100.11 and $106 \%$ for $\mathrm{FMCE}_{3}$ and $96.21,98.50$ and $97.50 \%$ for $\mathrm{TYCE}_{3}$ respectively. The potency of acetanominophen in the Analgesics, VBPC ${ }_{1}, \mathrm{MBPC}_{2}$ and $\mathrm{EMPC}_{3}$, was found to be $99.21,99.21$ and $97.72 \%$ respectively.

The results on quality assurance assessments on Blood tonic samples showed that the potency of ammonium citrate, thiamine (Vitamin $\mathrm{B}_{1}$ ) and pyridoxine (Vitamin $\mathrm{B}_{6}$ ) were 102,125 and $45.8 \%$ for $\mathrm{VBFT}_{1} ; 104.5,73.5$, and $111.5 \%$ for $\mathrm{FMMT}_{2}$ and 102, 125, 81.9\% for $\mathrm{TYBT}_{4}$. Ammonium citrate in $\mathrm{FMLT}_{3}$ was found to be $101 \%$.

Dissolution testing is performed to determine the rate at which the active pharmaceutical ingredient is released. The fraction of a dose of drug that is absorbed at its site of administration and reaches, in an unchanged form in systemic circulation largely depends, among other parameters, on dissolution rate. In the dissolution test for Metronidazole, sample VBMT 1 was found to have higher dissolution rate when compared with $\mathrm{SKMT}_{3}$ and $\mathrm{MBMT}_{2}$. Consequently, the quantity of Metronidazole in $\mathrm{VBMT}_{1}$ in the serum (bioavailability) is expected to be higher than other samples. For the Analgesics, sample $\mathrm{VBPC}_{1}$ has the highest percentage dissolution followed by sample $\mathrm{MBPC}_{2}$ and $\mathrm{EMPC}_{3}$ respectively, therefore, the quantity of the active ingredient in the sample VBPC 1 that will be available in patient's serum will be the highest followed by $\mathrm{MBPC}_{2}$ and $\mathrm{EMPC}_{3}$. All the samples were however, found to comply with the standard as stipulated in the BP monograph (BP, 2002).

It was evident from the results obtained from the assay determination that the Co-trimoxazole tablet with the best assay result was $\mathrm{VBCT}_{1}$ tablet compared with other samples $\left(\mathrm{SKCT}_{3}\right.$ and $\mathrm{EMCT}_{2}$ ). Even though the active ingredients of the three samples comply with the standard, they differ in terms of the amount of active ingredient obtained (milligram) and percentage yield.

The sample with the best assay result was $\mathrm{VBMT}_{1}$. The amount obtained and percentage yield for $\mathrm{MBMT}_{2}$ was higher than the amount claimed by the manufacturer while that of $\mathrm{SKMT}_{3}$ was lower. All the samples of Metronidazole were however; comply with specification in the standard reference books.

In the assay of cough expectorant syrup, the amount of diphenhydramine in $\mathrm{VBCE}_{1}$ was closer to the amount claimed by the manufacturer followed by $\mathrm{TYCE}_{3}$ and $\mathrm{FMCE}_{2}$. The amount $(\mathrm{mg})$ of ammonium chloride obtained 
Table 6. Assay results of the different pharmaceutical products investigated.

\begin{tabular}{|c|c|c|c|c|c|c|c|c|}
\hline $\mathbf{S} / \mathbf{N}$ & $\begin{array}{l}\text { Drugs/Brand } \\
\text { codes }\end{array}$ & Active ingredient(s) & $\begin{array}{l}\text { Analytical } \\
\text { procedure }\end{array}$ & $\begin{array}{l}\text { Amount } \\
\text { claimed } \\
(\mathrm{mg})\end{array}$ & $\begin{array}{l}\text { Amount } \\
\text { obtained } \\
\text { (mg) }\end{array}$ & $\begin{array}{c}\text { Assay } \\
\text { specification } \\
(\%)\end{array}$ & $\begin{array}{l}\text { Obtained } \\
\text { yield (\%) }\end{array}$ & Remark \\
\hline \multicolumn{9}{|c|}{ Co-trimoxazole tablet } \\
\hline 01 & $\mathrm{VBCT}_{1}$ & Trimethoprim & HPLC & 80 & 79.14 & 93-102 & 98.90 & Passed \\
\hline 02 & $\mathrm{EMCT}_{2}$ & Sulphamethoxazole & HPLC & 400 & 377 & 93-102 & 94.37 & Passed \\
\hline \multirow{2}{*}{03} & \multirow{2}{*}{$\mathrm{SKCT}_{3}$} & Sulphamethoxazole & \multirow[t]{2}{*}{ HPLC } & 400 & 385 & \multirow{2}{*}{$93-102$} & 96.28 & Passed \\
\hline & & Trimethoprim & & 80 & 77.16 & & 96.45 & Passed \\
\hline \multicolumn{9}{|c|}{ Metronidazole tablet } \\
\hline 04 & $\mathrm{VBMT}_{1}$ & Metronidazole & Spec. & 400 & 400 & $98-102$ & 100 & Passed \\
\hline \multicolumn{9}{|c|}{ Cough expectorant } \\
\hline \multirow{3}{*}{07} & \multirow{3}{*}{$\mathrm{VBCE}_{1}$} & Diphenhydramine $\mathrm{HCl}$ & HPLC & 14 & 13.89 & $90-110$ & 99.21 & Passed \\
\hline & & Ammonium Chloride & Titrimetry & 135 & 135 & $94-106$ & 99.98 & Passed \\
\hline & & Sodium citrate & Titrimetry & 57 & 57.87 & $95-106$ & 101.53 & Passed \\
\hline \multirow{3}{*}{08} & \multirow{3}{*}{$\mathrm{FMCE}_{3}$} & Diphenhydramine $\mathrm{HCl}$ & HPLC & 15 & 15.75 & $90-110$ & 105 & Passed \\
\hline & & Ammonium Chloride & Titrimetry & 130 & 130 & $94-106$ & 100.11 & Passed \\
\hline & & Sodium citrate & Titrimetry & 57 & 60 & $95-106$ & 106 & Passed \\
\hline 09 & $\mathrm{TYCE}_{3}$ & Diphenhydramine $\mathrm{HCl}$ & HPLC & 14 & 13.47 & $90-110$ & 96.21 & Passed \\
\hline 12 & $\mathrm{EMPC}_{3}$ & Acataminophen & Spec. & 500 & 489 & $95-105$ & 97.72 & Passed \\
\hline \multicolumn{9}{|c|}{ Blood tonic } \\
\hline \multirow{3}{*}{13} & \multirow{3}{*}{$\mathrm{VBFT}_{1}$} & Ammonium Citrtate & Spec. & 50 & 51 & $95.5-105$ & 102 & Passed \\
\hline & & Thiamine (Vitamin $B_{1}$ ) & HPLC & 3 & 3.8 & $110-150$ & 125 & Passed \\
\hline & & $\begin{array}{l}\text { Pyridoxine (Vitamin } \\
\mathrm{B}_{6} \text { ) }\end{array}$ & HPLC & 2 & 2.9 & $110-150$ & 45.83 & Passed \\
\hline \multirow{3}{*}{14} & & Ammonium Citrtate & Spec. & 54 & 56 & $95.5-105$ & 104.50 & Passed \\
\hline & $\mathrm{FMMT}_{2}$ & Thiamine (Vitamin $B_{1}$ ) & HPLC & 2 & 1.5 & $110-150$ & 73.50 & Failed \\
\hline & IVIIVII 2 & $\begin{array}{l}\text { Pyridoxine (Vitamin } \\
\mathrm{B}_{6} \text { ) }\end{array}$ & HPLC & 2 & 2.2 & $110-150$ & 111.50 & Passed \\
\hline 15 & $\mathrm{FMLT}_{3}$ & Ammonium Citrtate & Spec. & 200 & 202 & $95.5-105$ & 101 & Passed \\
\hline & & Ammonium Citrtate & Spec. & 85 & 87 & 95.5-105 & 102 & Passed \\
\hline 16 & $\mathrm{TYBT}_{4}$ & Thiamine (Vitamin $B_{1}$ ) & HPLC & 2 & 2.5 & $110-150$ & 125 & Passed \\
\hline 10 & $1 Y 014$ & $\begin{array}{l}\text { Pyridoxine (Vitamin } \\
\mathrm{B}_{6} \text { ) }\end{array}$ & HPLC & 2 & 1.6 & $110-150$ & 81.90 & Failed \\
\hline
\end{tabular}

HPLC = High Pressure Liquid Chromatography; Spec. $=$ Spectrophotometry. 
in $\mathrm{VBCE}_{1}$ and $F M C E_{2}$ were found to be the same with the expected standard. $\mathrm{FMCE}_{2}$ and $\mathrm{VBCE}_{1}$ contain high amount $(\mathrm{mg})$ of sodium citrate (active ingredients) while $\mathrm{TYCE}_{3}$ was lower. Of the three samples, the amount of sodium citrate obtained in $\mathrm{VBCE}_{1}$ was the highest, though all the samples are within specifications.

In the analysis of the Analgesics, the amount $(\mathrm{mg})$ of acetaminophen in $\mathrm{VBPC}_{1}$ was closer to the amount claimed by the manufacturer in the sample compared to samples $\mathrm{MBPC}_{2}$ and $\mathrm{EMPC}_{3} . \mathrm{MBPC}_{2}$ was found to be 6 $\mathrm{mg}$ lesser than what the manufacturer claimed. It was observed that $\mathrm{MBPC}_{2}$ is the most expensive of the three samples and most desired for by the people. This may be due to the higher disintegration rate as observed in the disintegration analysis, which may likely confer on it the faster onset of action which is mostly desired by the people. Comparing the result with that obtained by Akhilesh et al. (2014), it shows conformity.

For the Blood tonic sampled $\left(\mathrm{VBFT}_{1}, \mathrm{FMMT}_{2}, \mathrm{FMLT}_{3}\right.$, and $\mathrm{TYBT}_{4}$ ), the percentage of ammonium citrate obtained in all the samples were found to comply with the standard. The amount of ammonium citrate is found to be slightly higher than what manufacturer claimed e.g. VBFT 1 . From the assay assessment of vitamin B6 and B1, sample $\mathrm{VBFT}_{1}$ contained the highest amount of these vitamins because excess vitamins were added to compensate for any loss during storage. It was also clearly seen that Vitamins $\mathrm{B} 6$ in $\mathrm{TYBT}_{4}$ and vitamin $\mathrm{B} 1$ in $\mathrm{FMMT}_{2}$ fell below the standard and therefore failed the test.

\section{Conclusions}

This work has assessed the quality of five pharmaceutical products of different brands marketed in Nigeria. It was carried out to gather analytical data that could be used by consumers to determine whether their choice for any of these drugs should be based on the brand name, price or on the drug purity and composition. All values were compared with international standards. Except that the amount of Vitamins B6 in $\mathrm{TYBT}_{4}$ and vitamin B1 in $\mathrm{FMMT}_{2}$ fell below the standard and therefore failed the test, generally, most of the pharmaceutical products analysed complied with standards in the monographs. This implies that manufacturers of these products must have employed standard analytical methods and standard equipment for their production. It was also inferred that the choice of generics, on the part of the consumer, should not be based on the name of the company neither should it be based on the price (expensive or cheap) of the product but should rather be based on the analytical results (assay results, bio-pharmaceutical results, and statistical results) of the product and the projected bioequivalence which will culminate in the potency of such a product.

\section{Recommendations}

This study recommends that analysis should always be carried out on every batch of all pharmaceutical products so as to ensure their quality. It will be of great health consideration and consumer's safety if the production of drugs could always meet required standards set in standard reference books such as British pharmacopeia, US pharmacopeia and others before such products are released into the market for consumption because poor quality medicines present a serious public health problem (Johnston and Holt, 2013). In addition, standard analytical methods and standard equipment must be employed in analysis of all pharmaceutical products before marketing. The regulatory bodies should ensure that all batches are tested and issued quality assurance certificate and a quality control seal so as to boost the confidence of consumers. This will help to eliminate the production of sub-standard drugs so as to guarantee safety, promote good health and reduce morbidity and mortality as well as improving the life expectancy and improved health index of the nation.

\section{CONFLICT OF INTEREST}

The authors declare that they have no conflicts of interest.

\section{REFERENCES}

Akhilesh, K, Santhosh, K, Sanjay, K, Shiva, K., \& Shiva, S. (2014). Analysis of seven brands of paracetamol $500 \mathrm{mg}$ tablets used in hyderbad, using ultraviolet spectrophotometric and high performance liquid Chromatography (HPLC) methods. International Journal of Pharmaceutical Science and Research, 5(3), 951-955.

Ansel, H. C., Popovich, N. G., \& Allen, L. V. (1995). Pharmaceutical dosage forms and drug delivery systems. Williams and Wilkins, Sixth Edition. Pp. 182-193.

British Pharmacopeia (BP) (2002). British Pharmacopeia (Vol I) and Her Majesty's Stationery Office, University Press, Cambridge.

Cockburn, R., Newton, P. N., Agyarko, E. K., Akunyili, D., \& White, N. J. (2005). The global threat of counterfeit drugs: why industry and governments must communicate the dangers. PLoS Medicine, 2(4), e100.

Dulla, O., Sultana, S., \& Md. Hosen, S. (2018). In vitro comparative quality evaluation of different brands of esomeprazole tablets available in selected community pharmacies in Dhaka, Bangladesh. BMC Research Notes, 11, Article number 184.

European Union (EU) (2004). Directive 2004/27/EC of the European Parliament and of the Council of 31 March 2004 amending directive 2001/83/EC on the community code relating to medicinal products for human use. Official Journal of the European Union no. L-136/34, Apr 30.

Gupta, M. M., \& Patel, V. (2013). Formulation and evaluation oral dispersible tablet of cinnarizine. Journal of Drug Delivery and Therapeutics, 3(2), 12-17.

Gupta, M. M., \& Saini, T. R. (2009). Preformulation parameters characterization to design, development and formulation of vancomycin hydrochloride tablets for psudomembranous colitis. International Journal of Pharmaceutical Research and Delivery, 9(1), 1-7. 
Indian Pharmacopoeia (1996). Ministry of Health \& Family Welfare, Controller of Publication, 4th Edition, Government of India. 2, A144-A145.

Johnston, A., \& Holt, D. W. (2014). Substandard drugs: A potential crisis for public health. British Journal of Clinical Pharmacology, 78(2), 218-243.

Khar, R. K., Vyas, S. P., Ahmad, J. F., \& Jain, K. G. (2013). Lachman/liebermans: The theory and practice of industrial pharmacy. 4th edition. Delhi: CBS Publishers \& Distributor.

King, R. E., \& Schwarz, J. B. (1985). Oral solid dosage forms. In: Remingtons

Pharmaceutical Sciences. 17th edition, Mack Pub. Co., Easton, Pennyslvania. Pp. 1603-1641.

Musa, H., Sule, Y. Z. \& Gwarzo, M. S. (2011). Assessment of physicochemical properties of Metronidazole tablets marketed in Zaria, Nigeria. International Journal of Pharmacy and Pharmaceutical Sciences, 3(Suppl 3), 27-29.

Racchi, M., Govoni, S., Lucchelli, A., Capone, L., \& Giovagnoni, E. (2016). Insights into the definition of terms in European medical device regulation. Expert Review of Medical Devices, 13(10), 907-917.

Sarker, R., Rashid, S., Raju, A. A., Rana, M., Karim, M. F. B., Akter, R., Nayem, A., Howlader, A., Ming, L. C., \& Ismail, E. (2016). Evaluation of the pharmaceutical quality of different brands of ranitidine tablets manufactured in Bangladesh: A Pharmaceutical and Public Health Prospective, Journal of Applied Pharmaceutical Science, 6(1), 055-061.
US Pharmacopoeia (USP) (2014). United States Pharmacopoeia Convention, Thirty Seventh Edition. Pp. 342-351, 1571-1572.

World Health Organization (WHO) (2007). Quality assurance of pharmaceuticals: A compendium of guidelines and related materials. Good manufacturing practices and inspection. p 2.

World Health Organization (WHO) (2012). Medicines: Spurious/falsely labelled/falsified counterfeit labelled/falsified/counterfeit (SFFC) medicines. Retrieved 8th April 2014 from http://www.who.int/mediacentre/factsheets/fs275/en/.

Yamato, S., Sakai, M., \& Shimada, K. (1996). Quantitative analysis of chlorpheniramine maleate in cough and cold drugs by ion-pair high-performance liquid chromatography for the simultaneous determination of chlorpheniramine and maleate. Yakugaku zasshi: Journal of the Pharmaceutical Society of Japan, 116(4), 329-334. 